\title{
Mental Budgeting dan Motivasi Terhadap Pengelolaan Keuangan Individu
}

\author{
Eka Rosalina ${ }^{\mathrm{a},{ }^{*}, \text { Rida Rahim }^{\mathrm{b}} \text {, Tafdil Husnic }}{ }^{\mathrm{c}}$ and Fany Alfarisi ${ }^{\mathrm{d}}$ \\ ${ }^{a}$ PDIM, Universitas Andalas, ekarosalinapnp5@gmail.com, Indonesia \\ bPDIM, Universitas Andalas, ridarahim@eb.unand.ac.id, Indonesia \\ cPDIM, Universitas Andalas, tafdilhusni@eb.unand.ac.id, Indonesia \\ d PDIM, Universitas Andalas, fanyalfarisi@eb.unand.ac.id, Indonesia
}

\begin{abstract}
Budgeting cannot be separated from personality and by itself arises from the human individual - people who will make and run the budget. With the budget, financial management will be better. This research was conducted to find out the influence of mental budgeting and motivation on the financial management of individuals. This research was conducted through a questionnaire survey distributed to polytechnic students in 2021 who had taken budget and financial management courses. The sample from this study was 108 samples using Slovin and random sampling techniques. It was then continued with hypothesis testing using multiple linear regressions. The results of this study state that mental budgeting has a positive effect on individuals' financial management, and motivations positively affect personal financial management.
\end{abstract}

Keywords: Individual Financial Management, Mental Budgeting, Motivation, Budgeting, Financial Management.

*Corresponding author. E-mail: ekarosalinapnp5@gmail.com 


\section{Introduction}

Penganggaran merupakan salah satu alat manajemén individu dalam menetapkan tujuan, baik lingkungan individu, ataupun kelompok baik bisnis maupun non bisnis. Pada dekade belakangan ini sangatlah cepat berubah. Setiap individu membutuhkan anggaran untuk kemakmuran kehidupan, agar tidak adanya pemborosan keuangan yang berlebihan. Sebagai individu membutuhkan manajemen yang baik, agar menjadi sebuah antisipasi sebelum melakukan sesuatu supaya apa yang menjadi rencana dapat terorganisir dengan sebagai mana mestinya.

Zaman sekarang, adalah zaman konsumtif bagi para individu, dan saat ini banyak sekali produk yang menggoda bagi para kaula muda. Sehingga mereka lebih memilih pola hidup konsumtif dari pada melakukan saving ataupun investasi yang nantinya akan menunjang kesejahteraan hidup individu. Melakukan perencanaan anggaran adalah suatu yang sebaiknya dilakukan agar keuangan dapat di manage dengan baik. Sumber dari Badan Pusat Statistik di Indonesia, Sumatera Barat merupakan peringkat ke dua Rata-rata Pengeluaran Pakaian, Alas Kaki, dan Tutup Kepala per Kapita Sebulan tahun 2019, yaitu $55,8 \%$, dan yang pertama adalah DKI Jakarta yaitu $59,4 \%$. Sangat disayangkan bagi kaula muda, jika hal konsumtif menjadi sebuah kebiasaan.

Penganggaran adalah suatu faktor keperilakuan dari individu manusia yang akan membuat dan menjalankan anggaran. Keperilakuan dalam partisipasi anggaran mengacu kepada perilaku manusia. Manusia lah yang menyusun, memikirkan perencanaan dan menggerakkan anggaran. Di kaji secara Psikologi, sumber daya manusia adalah indicator penentu keberhasilan suatu usaha. Dengan ini sumber daya manusia wajib di kelola dengan baik agar meningkatkan efektifitas, efisiensi dan produktifitas. Individu menggunakan sumber daya kognitif dengan cara yang masuk akal, secara kolektif mereka sedang mengembangkan prosedur yang secara efektif mengatur transaksi ekonomi dan social (Gärling et al., 2009). Dalam kehidupan, transaksi yang terjadi sangatlah begitu kompleks, terutama keterkaitan terhadap transaksi pengeluaran. Oleh karena itu, penting bahwa pengetahuan ilmiah tentang perencanaan dan pengambilan keputusan dalam kehidupan.

Dengan telah diperolehnya mata kuliah anggaran, mahasiswa dituntut untuk dapat menerapkan anggaran keuangan untuk dapat mengelola keuangan dengan baik, hal ini akan memperlihatkan bagaimana perilaku keuangan mereka. Hal ini, mengajarkan mereka bahwa mengelola keuangan bukanlah hal sangat mudah diterapkan dalam kehidupan mereka, terkait dengan motivasi, dan mental dalam perilaku keuangan mereka. Bagi Individu, tujuan dari perilaku keuangan yang bertanggungjawab adalah untuk pengelolaan keuangan yang baik, sehingga dapat meningkatkan kenyamanan mereka dan kehidupan mereka ke depan secara pribadi. Hal ini dapat memberikan kontribusi kepada mahasiswa, dalam arti orang dengan pengelolaan keuangan yang dapat dipertanggungjawabkan yang nantinya akan cenderung tidak memiliki masalah keuangan seperti hutang yang akan bermasalah sehingga akan menimbulkan terganggu nya kegiatan perkuliahan. Lebih lanjut, mengkhawatirkan masalah keuangan menghilangkan sumber daya mental dan dapat menyebabkan kinerja akan lebih rendah (De Groot and Van Raaij, 2016) di lingkungannya. Pengetahuan financial, motivasi dan penerimaan pemahaman perencanaan dapat diterima dan dapat diterapkan dalam kehidupan. Peran individu sangatlah penting dalam mengurus keuangan karena hal ini bukanlah hal yang sangat mudah setiap individu karena individu pastinya memiliki kebutuhan yang menjadi kebutuhan utama yang diinginkan. Dalam hal ini peranan setiap individu haruslah bijak dalam pengambilan keputusan pengelolaan keuangan. Hal ini dapat mencegah pemborosan, yang merupakan tindakan pengeluaran tanpa memiliki manfaat dan kegunaan sehingga mengurangi perilaku konsumtif yang menyebabkan keuangan individu tidak terorganisir. Banyak sekali individu yang belum melakukan perencanaan dengan baik, tetapi mereka mengharapkan masa depan yang lebih baik. Secara hakiki, setiap individu dapat melakukan pengelolaan keuangan dengan baik jika telah melakukan pos pos pengeluaran dengan baik, dan dapat dilakukan dengan baik pula. Dalam hal ini sangatlah dibutuhkan motivasi individu dalam melakukannya, yang dapat dimulai dengan perencanaan terlebih dahulu.

Melakukan pengelolaan keuangan adalah motivasi seorang individu. Motivasi ini didasarkan atas perilaku individu, bagaimana motivasi individu dalam melakukan pengelolaan keuangan, yang paling penting terhadap pengeluaran yang nantinya akan dilakukan. Motivasi intrinsic dan extrinsic memainkan peranan yang sangat penting dalam keterlibatan sebuah perencanaan (Lau, Scully and Lee, 2018). Dalam perencanaan individu, menurut penulis, motivasi intrinsic yang sangat berpengaruh besar dalam perencanaan pengelolaan keuangan, hal ini 
disebabkan motivasi intrinsik merupakan kesadaran dalam diri individu dalam melakukan manajemen diri dengan pengendalian diri yang efektif. Dengan adanya motivasi intrinsic dapat memberikan energy sehingga menciptakan keinginan agar semua tujuan dan apa yang dicita-citakan individu dapat terlaksana dengan baik.

Akuntansi Mental adalah konsep kunci dalam penganggaran keuangan yang dapat mencakup baik efek perilaku manusia pada cara model keuangan dibangun dan efek dari cara model keuangan dibangun pada perilaku manusia. Akuntansi mental mengacu kepada pemisahan psikologis ekonomi (Antonides, Manon de Groot and Fred van Raaij, 2011). Misalnya individu menjaga anggaran belanja makanan mingguan secara mental terpisah dari anggaran hiburan mingguan atau pakaian mingguan (Healt and soll, 2016). Anggaran mental terkait dengan asal keuangan atau pendapatan dan pengeluaran pembayaran. Akuntansi mental diasumsikan memiliki implikasi terhadap perilaku individu yang menunjukkan bahwa, jika anggaran habis diakhir periode, individu mengatakan memiliki kecenderungan konsumsi yang besar, yang tidak mempertimbangkan saving masa depan. Hal ini sangat mempengaruhi mental budgeting. Penganggaran mental adalah bentuk spesifik dari akuntansi mental.

Mental Budgeting konsisten dengan penelitian tentang akuntansi mental (Henderson and Peterson, 1992), (Zhang and Sussman, 2018) yang menunjukkan bahwa orang menggunakan sumber daya secara berbeda berdasarkan cara mereka. Ide mental budgeting, yang disebut oleh (Thaler 1985, Zhang \& Sussman, 2018)) sebagai "proses penganggaran," lebih jauh. Bagian penting dari mental budgeting adalah konsep alokasi. Dalam konteks ini, tidak jauh berbeda dengan penganggaran yang sebelumnya dijelaskan oleh (Heath dan Soll,1996). Sebagian uang disimpan terpisah dari yang lain dengan mengalokasikan nya untuk tujuan tertentu. Hal ini dilakukan baik dengan memisahkannya secara fisik (misalnya, dengan menggunakan tabungan kecil atau rekening bank terpisah), atau dengan menggunakan bentuk kategorisasi mental (misalnya, dengan memiliki anggaran yang berbeda dalam pikiran untuk jenis pengeluaran yang berbeda). Dengan hal ini, dapat melakukan pengelolaan keuangan dengan baik dan efektif.

Dengan demikian penelitian ini melihat bagaimana perilaku individu mengenai motivasi dan mental budgeting dalam pengelolaan keuangan individu. Studi ini menggunakan kuesioner yang dirancang sehingga dapat memperoleh pandangan pribadi mengenai perilaku individu dalam pengelolaan keuangan. Dan sebagai unit analisis disini adalah Mahasiswa yang telah memperoleh mata kuliah anggaran dan manajemen keuangan untuk melihat bagaimana mereka dalam mengambil keputusan pengelolaan keuangan dari aspek perilaku keuangan. Dalam penelitian ini diangkat lah masalah yang sudah dijelaskan sebelumnya dalam latar belakang, adalah: apakah mental budgeting dan motivasi berpengaruh pada pengelolaan keuangan individu?.

\section{Tinjauan Literatur}

\section{Theory of Planned Behavior (TPB)}

Penelitian ini akan menggunakan theory planned behavior (TPB). Teori ini dikembangkan oleh teori theory of reasoned action (TRA), dimana teori ini ditunjukkan untuk memprediksi perilaku individu secara spesifik. Tema utama teori ini adalah bahwa niat perilaku merupakan cara terbaik untuk memprediksi dan menjelaskan seseorang perilaku. Niat berperilaku ditentukan pada prilaku sikap, norma yang subjektif dan kontrol terhadap perilaku. TPB telah digunakan untuk memprediksi berbagai perilaku (Habibah et al., 2018).

\section{Pengelolaan keuangan}

Pengelolaan adalah suatu sumber daya yang efisien dan efektif dalam adanya sebuah kegiatan. Pengelolaan keuangan adalah sesuatu yang dilakukan oleh individu yang digunakan untuk penyelenggaraan berjalannya kehidupan individu dalam mencapai sesuatu yang dinginkan atau ingin diraih oleh individu itu sendiri. Pengelolaan keuangan adalah sebagai suatu pengelolaan terhadap kegiatan dan fungsi keuangan yang nantinya akan ada pos-pos tertentu dalam penggunaan keuangan. Pengelolaan keuangan merupakan suatu kegiatan dalam mewujudkan apa yang menjadi tujuan terutama dalam hal keuangan untuk waktu yang akan datang yang telah direncanakan dengan baik. Pengelolaan keuangan yang terjadi dalam kehidupan meliputi pengelolaan keuangan secara pribadi yang dilakukan oleh individu, sebuah keluarga, dan suatu perusahaan yang direncanakan suatu kelompok organisasi. Dengan adanya manajemen keuangan merupakan bagian yang sangat penting dalam menyelesaikan masalah ekonomi, baik masalah perekonomian individu, perekonomian keluarga, maupun perekonomian perusahaan. Tujuan secara umum dalam melakukan 
pengelolaan keuangan, adalah: menginginkan dana sesuai yang diharapkan individu untuk waktu yang akan datang, menjaga dan menambah kekayaan yang dimiliki, arus kas dapat terkontrol dengan baik (penerimaan dan pengeluaran dalam hal keuangan), Melakukan manajemen risiko dan mengatur manajemen resiko investasi dengan baik dan mengkoordinir keuangan hutang dan piutang.

\section{Mental Budgeting}

Penganggaran mental merupakan bagian dari akuntansi mental. Anggaran dapat memainkan peran penting dalam bagaimana individu mengelola kehidupan keuangan mereka, baik untuk jangka pendek (misalnya, memprioritaskan pengeluaran di berbagai kategori) dan untuk perencanaan keuangan jangka panjang (misalnya, menentukan berapa banyak uang yang akan disisihkan untuk masa depan). Di luar individu, anggaran konsumen dapat membentuk permintaan akan berbagai produk dan layanan. individu harus didorong untuk membuat anggaran. Namun yang mengejutkan, hanya sedikit yang diketahui tentang bagaimana orang-orang sebenarnya menganggarkan. Sebagian besar survei tentang penganggaran bertujuan terutama untuk menangkap keterlibatan - apakah individu memiliki anggaran atau tidak. Misalnya, Studi Kemampuan Keuangan Nasional 2015 memperkirakan bahwa lebih dari setengah individu (56\%) melaporkan memiliki anggaran rumah tangga (Lin et al., 2016). Untuk perencanaan keuangan jangka panjang, survei peserta dalam rencana yang dikelola oleh TIAA (Teachers Insurance and Annuity Association of America) melaporkan bahwa sekitar 39,01\% responden setuju atau sangat setuju bahwa setiap individu telah menghabiskan waktu untuk mengembangkan rencana yang diinginkan. Meskipun informatif, sebagian besar survei ini menahan diri dari pertanyaan penting tentang bagaimana atau mengapa penganggaran dilakukan (Zhang \& Sussman, 2018). Penganggaran mental dapat digambarkan sebagai proses di mana orang mengategorikan dan memberi label uang mereka untuk pengeluaran atau kategori tabungan tertentu, disertai dengan penggunaan "anggaran" untuk membatasi pengeluaran di luar kategori. Mereka mengategorikan dan memberi label uang mereka untuk tujuan tertentu (misalnya, "hiburan" atau "bahan makanan") dan melacak pengeluaran mereka terhadap batas pengeluaran atau anggaran pribadi tertentu yang telah direncanakan sebelumnya. Karena itu, proses yang digunakan untuk memisahkan dan melacak alokasi dana terhadap kategori yang berbeda dengan pengeluaran yang telah ditentukan sebelumnya atau pembatasan anggaran (Zhang \& Sussman, 2018).

$\mathrm{H}_{1}$ : Mental budgeting berpengaruh pada Pengelolaan Keuangan individu.

\section{Motivasi}

Motivasi yaitu suatu keinginan seorang individu dalam melakukan suatu tindakan berperilaku dengan bentuk motivasi dalam diri yang akan mengacu pada sebab munculnya sebuah sikap berprilaku. Motivasi diartikan suatu keinginan untuk mencapai seuatu yang menjadi harapan sebuah kesuksesan individu. Motivasi justru dapat dilihat dari berbagai segi untuk mencapai sebuah kesuksesan pada berbagai segi kehidupan melalui peningkatan keinginan, kemampuan dan kemauan. Literature tentang motivasi individu menunjukan bahwa motivasi merupakan penentu yang kuat dalam perilaku individu. Ketika individu memiliki motivasi yang tinggi, maka hasil yang dihasilkan cenderung akan tinggi, dan begitu juga sebaliknya (Deci\&Ryan, 2012). Jadi motivasi memegang peranan penting dalam pengelolaan keuangan individu. Penelitian menunjukkan bahwa banyak tujuan hidup individu dapat dikelompokkan menjadi dua kategori: motivasi intrinsik seperti pertumbuhan, hubungan, dan komunitas, dan aspirasi ekstrinsik seperti kekayaan, ketenaran, dan citra (Deci\&Ryan, 2012). Penelitian ini terfokus kepada motivasi intrinsic, dikarenakan bagaimana individu tersebut dalam melakukan pengelolaan keuangan.

$\mathrm{H}_{2}$ : Motivasi berpengaruh pada Pengelolaan Keuangan individu.

\section{Kerangka Pemikiran}

Dengan hipotesis dan penelitian terdahulu diatas, maka dapat disajikan dalam suatu kerangka pikir untuk dapat memperjelas penelitian dengan variabel yang menjadi elemen pengukuran. Penelitian ini menggunakan kerangka piker penulis disajikan pada gambar 1 di bawah ini.

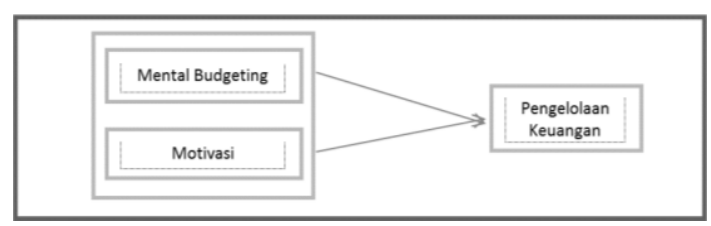

Gambar 1. Kerangka Pemikiran 


\section{Metode Penelitian}

\section{Desain Penelitian}

Desain penelitian yaitu pendekatan kuantitatif, yang merupakan penelitian dijelaskan melalui pengujian teori yang sudah ada sebelumnya dengan pengukuran variabel yang menjadi hipotesis dengan angka, dalam sebuah persamaan dan melakukan analisa data dengan prosedur statistik. Metode yang digunakan dalam penelitian ini adalah metode kuantitatif yang bertujuan untuk mengumpulkan, mengolah, menguji dan menganalisa suatu data berupa angka-angka dan di olah secara statistik. Penelitian ini dimaksudkan untuk mengidentifikasi bagaimana penerimaan materi pembelajaran dalam perkuliahan anggaran jika diterapkan dalam kehidupan mahasiswa yang dilihat dari aspek perilaku keuangan melalui motivasi dan mental budgeting dalam pengelolaan keuangan mereka setelah mereka memperoleh mata kuliah anggaran dan manajemen keuangan.

\section{Sampel}

Populasi adalah sejumlah secara menyeluruh subjek dari penelitian yang menjadi objek yang diteliti. Dalam Sugiyono (2017), populasi merupakan objek atau subjek yang dianggap memiliki kualitas dan karakteristik oleh peneliti dalam suatu objek yang nantinya dapat di tarik kesimpulan setelah melalui pengolahan data. Populasi dari penelitian ini adalah Mahasiswa tahun akhir Politeknik Negeri Padang Jurusan akuntansi di tahun 2021 yang sudah mendapatkan mata kuliah Anggaran dan manajemen Keuangan. Penelitian ini, dengan menyebarkan kuesioner secara langsung kepada mahasiswa yang sudah memiliki pemahaman mengatur keuangan, sehingga waktu untuk penelitian ini efisien. Diambil Sampel penelitian adalah yang menjadi populasi sebagai sumber data yang mewakili seluruh populasi. Sampel dalam penelitian yang menggunakan formula slovin. Berdasarkan rumus besar sampel penelitian minimal oleh slovin di atas, maka penelitian mempunyai 150 responden dalam sebuah populasi penelitian. Peneliti menetapkan margin of error-nya sebesar 0.05 agar jumlah ukuran sampel yang diambil sesuai dengan ketentuan tersebut. Maka yang didapatkan minimal adalah 108 responden dari total keseluruhan populasi.

\section{Metode Pengumpulan Data}

Pengumpulan data dengan menyebarkan kuesioner. Kuesioner ini merupakan indicator pertanyaan yang akan menjawab dari hasil penelitian yang ingin dilakukan dan juga berisi masalah yang terkait dengan objek ataupun subjek yang akan diteliti. Kuesioner dengan bentuk skala likert dengan adanya peringkat jawaban dari pertanyaan yang tobit, dan kuesioner ini berupa pertanyaan positif dan ini akan dibagikan kepada responden untuk diisi, sebelum dilakukannya pengumpulan data secara menyeluruh, terlebih dahulu dilakukan uji instrument penelitian dengan menggunakan uji reabilitas dan validitas. kemudian kuesioner di berikan kepada responden dan responden mengembalikannya kepada peneliti yang nantinya menjadi sumber data yang akan menjadi olahan peneliti dalam menemukan hasil dari rumusan masalah yang timbul.

\section{Instrumen Penelitian}

Penelitian ini menggunakan Instrumen adalah kuesioner yang diberikan oleh peneliti adalah kuesioner yang akan disebarkan kepada objek peneliti. Kuesioner terbagi menjadi dua karakteristik. Pada karakteristik pertama berisikan pertanyaan kepada responden yang terdiri dari Nama, Jenis Kelamin, dan Umur. Karakteristik kedua berisi variabel indikator pertanyaan yang berhubungan dengan hipotesis independen variabel (Mental Budgeting dan Motivasi) dan dependen variabel (Pengelolaan Keuangan). Variabel dependen dan independen tersebut akan diukur dengan menggunakan skala likert yang berisikan indicator variabel yaitu mental budgeting, motivasi dan pengelolaan keuangan.

\section{Hasil Penelitian}

\section{Uji Kualitas}

Ada dua yang diujikan dalam uji kualitas data terutama uji dari kuesioner.

1. Uji Validitas sebuah kuesioner dinyatakan valid jika setiap indikator pertanyaan pada kuesioner mampu dapat menyatakan seuatu yang oleh kuesioner tersebut. Apabila diperoleh nilai $r$ hitung lebih besar dari nilai $r$ tabel dan bernilai positif maka indikator pertanyaan dinyatakan 
valid. Pengujian validitas instrumen penelitian ini dilakukan terhadap 115 responden. Perhitungan nilai $r$ hitung dengan $r$ table, dengan nilai $r$ tabel sebesar 0,2373 dan dengan tingkat signifikansi di bawah 0,05. Dari Hasil olahan dengan menggunakan SPSS maka disimpulkan semua indikator pertanyaan adalah variabel Valid, karena semua indicator dinyatakan besar dari $r$ tabel.

2. Uji reabilitas, Uji dilakukan terhadap indikator pertanyaan yang valid yang didapatkan dari hasil uji validitas. Dimana variabel dinyatakan reliabel jika nilai Cronbach's Alpha $>0,70$. Hasil dari pengolahan data didapat nilai Cronbach's Alpha sebesar 0,845, sehingga data dikatakan reliabel.

\section{Uji Asumsi Klasik}

Berikut uji asumsi klasik yang digunakan pada penelitian ini.

1. Uji normalitas pada penelitian ini menggunakan 2 uji, yaitu grafik dan One-Sample KolmogorovSmirnov Test.

a. Hasil Uji Normalitas dengan Grafik

Pengujian normalitas dapat dideteksi dengan memperhatikan gambar dibawah ini bahwa titik mendekati atau sebarannya berada pada sumbu diagonal dari grafik normal. Berikut adalah hasil uji normalitas data penelitian ini.

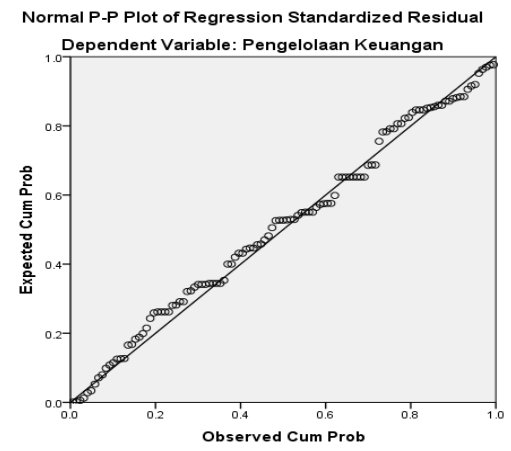

Gambar 2. Grafik Uji Normalitas dengan Grafik

Sumber: Output SPSS diolah, 2021

b. Hasil Uji Normalitas dengan One-Sample Kolmogorov-Smirnov Test

Berikut hasil uji normalitas dengan One-Sample Kolmogorov-Smirnov Test.
Tabel 1

Uji Normalitas dengan One-Sample Kolmogorov-Smirnov Test

\begin{tabular}{llr}
\hline & & \multicolumn{2}{c}{$\begin{array}{c}\text { Unstandardized } \\
\text { Residual }\end{array}$} \\
& & 115 \\
$\mathrm{~N}$ & Mean & .0000000 \\
Normal & Std. & \\
Parameters ${ }^{\mathrm{a}, \mathrm{b}}$ & Deviation & 3.71922310 \\
& Absolute & .066 \\
Most Extreme & Positive & .044 \\
& Negative & -.066 \\
& & .066 \\
Test Statistic & & $.200^{\mathrm{c}, \mathrm{d}}$ \\
Asymp. Sig. (2-tailed) & & \\
\hline
\end{tabular}

Sumber: Output SPSS diolah, 2021

Uji statistik One-Sample Kolmogorov-Smirnov Test yang digunakan dalam uji normalitas diperoleh nilai kolmogorof-smirnov $z$ sebesar 0,066 dan asymp. sig. (2-tailed) sebesar 0,200 > signifikansi $5 \%$ atau 0,05 , maka dapat disimpulkan data berdistribusi normal.

2. Uji Multikolinearitas dapat dilihat dari nilai tolerance dan lawannya, serta dari Variance Inflation Factor (VIF). Kedua ukuran ini menunjukkan setiap variabel independen manakah yang dijelaskan oleh variabel independen lainnya. Hasil uji multikolonieritas dapat dilihat pada Tabel 2.

Tabel 2

Multikolonieritas

\begin{tabular}{|c|c|c|c|c|c|c|c|}
\hline \multirow[b]{3}{*}{ Model } & \multirow{2}{*}{\multicolumn{2}{|c|}{$\begin{array}{c}\begin{array}{c}\text { Unstandardized } \\
\text { Coefficients }\end{array} \\
\text { Std. }\end{array}$}} & \multirow{3}{*}{$\begin{array}{c}\begin{array}{c}\text { Standardized } \\
\text { Coefficients }\end{array} \\
\text { Beta }\end{array}$} & \multirow[t]{3}{*}{$\mathbf{t}$} & \multirow[t]{3}{*}{ Sig. } & \multicolumn{2}{|c|}{$\begin{array}{c}\text { Collinearity } \\
\text { Statistics }\end{array}$} \\
\hline & & & & & & $\overline{\text { Tolerance }}$ & VIF \\
\hline & B & Error & & & & & \\
\hline 1 (Constant) & 8.873 & 3.3748 & & 2.367 & 0.020 & & \\
\hline $\begin{array}{l}\text { Metal } \\
\text { Budgeting }\end{array}$ & .889 & .147 & .471 & 6.034 & .000 & .859 & 1.164 \\
\hline Motivasi & .990 & .260 & .297 & 3.802 & .000 & .859 & 1.164 \\
\hline
\end{tabular}

Hasil uji multikolinearitas menunjukkan bahwa nilai tolerance yang dihasilkan untuk variabel mental budgeting dan motivasi masing-masing adalah 0,859 dan 0,859. Sedangkan nilai VIF 
yang dihasilkan untuk setiap variabel pengelolaan keuangan dan kompetensi sumber daya manusia adalah 1.164 dan 1.164 dimana nilai tolerance untuk setiap variabel yang digunakan di atas 0,1 dan nilai variance inflation factor (VIF) di bawah 10. Berdasarkan hasil uji multikolinearitas, maka dapat disimpulkan bahwa semua variabel independen dalam model regresi terbebas dari masalah multikolinearitas dan layak digunakan dalam penelitian ini.

3. Uji heteroskedastisitas dapat dilihat dengan grafik plot. Deteksi tidak adanya heteroskedastisitas dapat dilakukan dengan melihat ada tidaknya pola tertentu pada grafik scatterplot antara SRESID dan ZPRED.

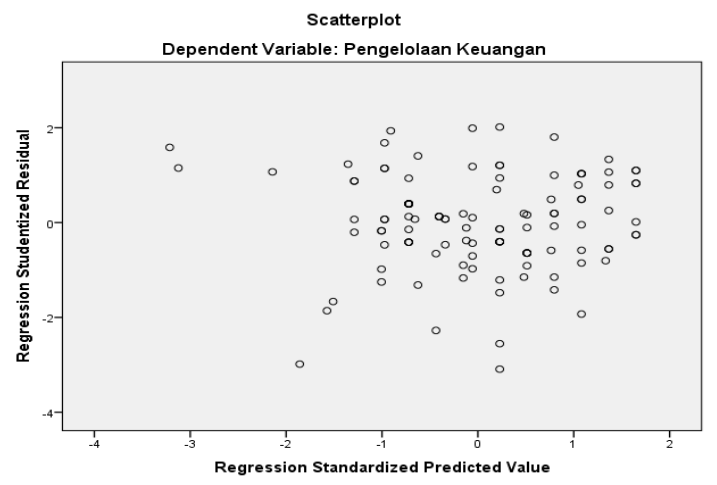

Gambar 3 Uji heteroskedastisitas

Sumber: Output SPSS diolah, 202

Terlihat di gambar adanya titik penyebaran secara acak serta tersebar baik di atas maupun di bawah angka 0 pada sumbu Y sehingga dapat disimpulkan tidak terjadinya heteroskedastisitas pada model regresi ini, sehingga model regresi layak dipakai untuk memprediksi Pengelolaan keuangan pada variabel dependen.

\section{Analisis Regresi Berganda}

Pengujian terakhir yaitu dengan regresi berganda dilakukan untuk melihat pengaruh dari variabel independen terhadap variabel dependen. Dengan hasil olahan sebagai berikut.
Tabel 3

Analisis Regresi Berganda

\begin{tabular}{lccccc}
\hline & \multicolumn{2}{c}{$\begin{array}{l}\text { Unstandardize } \\
\text { d Coefficients }\end{array}$} & $\begin{array}{c}\text { Standardized } \\
\text { Coefficients }\end{array}$ & t & Sig. \\
\cline { 2 - 4 } Model & B & Err. & Beta & & \\
\hline 1 (Constant) & 8.873 & 3.3748 & & 2.367 & 0.020 \\
$\begin{array}{l}\text { Metal } \\
\text { Budgeting }\end{array}$ & .889 & .147 & .471 & 6.034 & .000 \\
Motivasi & .990 & .260 & .297 & 3.802 & .000 \\
\hline
\end{tabular}

Berikut persamaan dari regresi berganda.

$$
\mathrm{Y} 1=8.873+0,889 \mathrm{X} 1+0.990 \mathrm{X} 2+\mathrm{e}
$$

Dari persamaan diatas, menyiratkan bahwa mental budgeting (X1) bernilai 0,889 yang artinya bahwa adanya kenaikan $88,9 \%$ pengelolaan keuangan individu dengan adanya peningkatan Mental budgeting. Serta adanya peningkatan pengelolaan keuangan dengan meningkatnya motivasi (X2) sebesar $99 \%$

\section{Pembahasan}

\section{Pengaruh Mental Budgeting pada Pengelolaan Keuangan Individu}

Dari uji yang telah dilakukan bahwa mental budgeting berpengaruh positif signifikan terhadap pengelolaan keuangan dengan nilai signifikansi $\mathrm{t}$ sebesar 0,000, dalam hal ini lebih kecil dari 0,005 yang artinya H1 diterima. Mental budgeting dalam anggaran memainkan peran penting terkait bagaimana individu mengelola kehidupan keuangan mereka, baik untuk jangka pendek dan untuk perencanaan keuangan jangka. Mental budgeting sangat membantu individu dalam melakukan pengelolaan keuangan, yaitu dengan mencadangkan uang untuk keperluan seperti makanan, pakaian, dan transportasi. Setiap individu dapat melakukan saving untuk masa depan karena setiap individu percaya bahwa semua dapat diperhitungkan dalam hal pendapatan dan pengeluaran. 


\section{Pengaruh Motivasi pada Pengelolaan Keuangan Individu}

Dari uji yang telah dilakukan bahwa motivasi berpengaruh positif signifikan terhadap pengelolaan keuangan dengan nilai signifikansi t sebesar 0,000 , dalam hal ini lebih kecil dari 0,005 yang artinya $\mathrm{H} 2$ diterima. Motivasi diukur dengan indikator psikologis. Jika motivasi tinggi dalam memperoleh sesuatu, maka motivasi pengelolaan keuangan juga akan lebih tinggi. Dengan motivasi masa depan yang lebih baik, maka pengelolaan keuangan yang didapatkan dan dikeluarkan dapat di-manage dengan baik. Melalui motivasi ini juga, timbul keingintahuan dalam me-manage keuangan, baik itu di bangku kuliah maupun di luar kuliah.

\section{Kesimpulan}

Penelitian ini bertujuan untuk mengetahui apakah mental budgeting dan motivasi berpengaruh terhadap pengelolaan keuangan individu. Hasil pengujian menyatakan bahwa mental budgeting berpengaruh positif signifikan terhadap pengelolaan keuangan, dengan nilai signifikansi sebesar $0,000<0,05$ dan $\mathrm{t}$ hitung sebesar 6,034. Hal ini menunjukkan bahwa semakin bagus mental budgeting yang dilakukan oleh individu maka pengelolaan keuangannya pun akan semakin meningkat.

Selain itu, hasil pengujian motivasi terhadap pengelolaan keuangan menunjukkan bahwa terdapat pengaruh positif signifikan terhadap pengelolaan keuangan, dengan nilai signifikansi sebesar 0,000 < 0,05 dan t hitung sebesar 3,082. Hal ini menunjukkan bahwa semakin bagus motivasi yang dilakukan oleh individu, maka pengelolaan keuangannya pun akan semakin meningkat.

Penelitian ini memiliki beberapa keterbatasan. Pertama, metode pengambilan sampel pada penelitian ini menggunakan formula slovin, dengan populasi mahasiswa tahun akhir Politeknik Negeri Padang Jurusan akuntansi di tahun 2021 yang sudah mendapatkan mata kuliah Anggaran dan manajemen Keuangan, dan jumlah minimal responden yang harus didapat hanya sebanyak 108. Kedua, penelitian ini hanya melakukan pengujian terhadap mental budgeting dan motivasi, sehingga masih banyak faktor atau variabel lainnya yang tidak digunakan dalam penelitian ini dan menyebabkan kurangnya informasi yang bisa digunakan untuk melakukan analisis lebih jauh.

Berdasarkan keterbatasan tersebut, terdapat dua saran untuk penelitian selanjutnya. Pertama, penelitian selanjutnya diharapkan dapat memperluas cakupan populasi sampel agar memperoleh responden yang lebih banyak. Kedua, penelitian selanjutnya dapat menambah variabel lain.

\section{Referensi}

Antonides, G., Manon de Groot, I. and Fred van Raaij, W. (2011) 'Mental budgeting and the management of household finance', Journal of Economic Psychology, 32(4), pp. 546-555. doi: 10.1016/j.joep.2011.04.001

Deci, E. L. and Ryan, R. M. (2012) Motivation, Personality, and Development Within Embedded Social Contexts: An Overview of Self-Determination Theory, The Oxford Handbook of Human Motivation. doi: 10.1093/oxfordhb/9780195399820.013.0006.

De Groot, I. M. and Van Raaij, W. F. (2016) 'The role of mental budgeting in healthy financial behavior: a survey among selfemployed entrepreneurs', Applied Studies in Agribusiness and Commerce, 10(2-3), pp. 15-25. doi: 10.19041/apstract/2016/2-3/2.

Habibah, U. et al. (2018) 'Household behavior in practicing mental budgeting based on the theory of planned behavior', Financial Innovation, 4(1). doi: 10.1186/s40854-018-0108-y.

Heath, C. and Soll, J. (1996) 'Mental budgeting and consumer decisions', Journal of Consumer Research, 23(1), pp. 40-52. doi: 10.1086/209465.

Henderson, P. W. and Peterson, R. A. (1992) 'Mental Accounting and Categorization, Organizational Behavior and Human Decision Processes, 51(1), pp. 92-117.

Lau, C. M., Scully, G. and Lee, A. (2018) 'The effects of organizational politics on employee motivations to participate in target setting and employee budgetary participation', Journal of Business Research, 90, pp. 247-259. doi: 10.1016/j.jbusres.2018.05.002.

Sugiyono. 2017. Metode Penelitian Kuantitatif, Kualitatif, dan R\&D. Bandung: Alfabeta.

Lin, J. T., Bumcrot, C., Ulicny, T., Lusardi, A., Mottola, G., Kieffer, C., \& Walsh, G. (2016). Financial capability in the United States 2016. FINRA Investor Education Foundation Retrieved from http://www.usfinancial capability.org /download /NFCS_2015_Report_Natl_Findings.pdf

Thaler, R. H. (2008) 'Mental accounting and consumer choice', Marketing Science, 27(1), pp. 15-25. doi: 10.1287/mksc. 1070.0330 .

Zhang, C. Y. and Sussman, A. B. (2018) 'Perspectives on mental accounting: An exploration of budgeting and investing', Financial Planning Review, 1(1-2), p. e1011. doi: 10.1002/cfp2.1011. 